\title{
COMPARISON OF PREGABALIN AND NORTRIPTYLINE ON EFFICACY AND SAFETY IN POSTHERPETIC NEURALGIA
}

\author{
KANIKA KHAJURIA ${ }^{1}$, SEEMA GUPTA ${ }^{1}$, DEV RAJ DOGRA ${ }^{2}$, DINESH KUMAR ${ }^{3}$, VIJAY KHAJURIA ${ }^{1 *}$
}

${ }^{1}$ Department of Pharmacology, Government Medical College, Jammu, Jammu and Kashmir, India. ${ }^{2}$ Department of Dermatology and Venereology, Government Medical College, Jammu, Jammu and Kashmir, India. ${ }^{3}$ Department of Community Medicine, Government Medical College, Jammu, Jammu and Kashmir, India. Email: vijaykhaj@yahoo.co.in.

Received: 18 April 2021, Revised and Accepted: 31 May 2021

ABSTRACT

Objectives: Antidepressants and anticonvulsants are most commonly prescribed in postherpetic neuralgia (PHN). The aim of the present study was to compare the efficacy and safety of pregabalin and nortriptyline in patients of PHN.

Methods: The present study was conducted in 48 patients of PHN attending outpatient department of Dermatology, GMC Jammu. After obtaining written consent, the enrolled patients were randomized into two groups, one group was given pregabalin $150 \mathrm{mg}$ orally per day, and other group was treated with nortriptyline $25 \mathrm{mg}$ orally per day and were followed up to 8 weeks. Patients were assessed on numerical rating scale (NRS), Leeds assessment of neuropathic symptoms and signs (LANSS). Safety of the drugs was monitored by adverse drug reactions (ADRs).

Results: All patients were over 57 years and thoracic dermatome was most affected. Both drugs significantly reduced NRS and LANSS (p<0.0001). However, on comparison pregabalin was found to be better than nortriptyline at 8 weeks on mean NRS ( $p=0.0073)$, LANSS ( $p=0.0032)$. Total of six mild ADRs occurred, two in group pregabalin and four in nortriptyline treated group.

Conclusion: Both pregabalin and nortriptyline were effective in patients of PHN, but pregabalin was found to be better than nortriptyline at 8 weeks. Both drugs were well tolerated, though pregabalin had lesser number of ADRs.

Keywords: Postherpetic neuralgia, Pregabalin, Nortriptyline, Numerical rating scale, Leeds assessment of neuropathic symptoms and signs.

(C) 2021 The Authors. Published by Innovare Academic Sciences Pvt Ltd. This is an open access article under the CC BY license (http://creativecommons.org/ licenses/by/4.0/) DOI: http://dx.doi.org/10.22159/ajpcr.2021v14i7.41872. Journal homepage: https://innovareacademics.in/journals/index.php/ajpcr

\section{INTRODUCTION}

Postherpetic neuralgia (PHN) is a painful complication that occurs after herpes zoster infection due to damage of peripheral nerves by the reactivation of the varicella zoster virus. Pain is constant or intermittent and burning, stabbing, or itching in character and may affect quality of sleep [1]. No treatment can completely prevent PHN, though starting early antiviral drugs within $72 \mathrm{~h}$ of onset of skin lesions can be beneficial. But still 20\% patients suffer from PHN despite early antiviral treatment [2].

Treatment of PHN involves use of tricyclic antidepressants (TCAs), serotonin-norepinephrine reuptake inhibitors, opioids, anticonvulsants, and intrathecal corticosteroids [3]. TCAs are most frequently used and cause inhibition of reuptake of serotonin and/or norepinephrine by presynaptic neuronal membrane, desensitization of adenylyl cyclase, and activation of GABA-B receptors [4]. Nortriptyline, a metabolite of amitriptyline is preferred because of its better safety profile.

Gabapentinoids are effective and pregabalin has been approved by Food and Drug Administration for the treatment of PHN [5]. Pregabalin binds with alpha2-delta protein subunit of presynaptic voltage-gated calcium channels and causes inhibition of excitatory neurotransmitters in the pain pathways of both central and peripheral nervous system [6]. Pregabalin is preferred over gabapentin due to better pharmacokinetic profile.

Although number of studies have examined the efficacy of TCAs and anticonvulsants in PNH $[7,8]$, however there is a paucity of literature regarding their comparison and in the present trial pregabalin and nortriptyline were compared for their efficacy in reducing pain and safety in patients of PHN.

\section{METHODS}

The present prospective, randomized, open label, and parallel trial was conducted in the Department of Pharmacology in collaboration with Department of Dermatology, Government Medical College Jammu to evaluate and compare the efficacy and safety of pregabalin and nortriptyline in PHN patients after taking approval from the Institutional Ethics Committee.

Patients reporting to the dermatology outpatient department, diagnosed as PHN by the dermatologist with moderate to severe pain were included in study and written, informed consent was obtained.

\section{Inclusion and exclusion criteria}

Patients of both genders $\geq 18$ years of age, diagnosed as PHN and having visual analog scale (VAS) pain score (VAS) $\geq 40 \mathrm{~mm}$ and who gave consent were included in the study. While patients with pregnancy and lactation, hypersensitivity to any of the test drugs, cardiac disease, seizure disorder, liver disease, impaired kidney functions, already on gabapentinoids or TCAs, severe depression with suicidal tendency or suffering from any other significant pain conditions (HIV infection, diabetic neuropathy, cancer pain, fibromyalgia) were excluded from the study.

Treatment protocol: Before intervention, complete clinical evaluation was done. The patients based on inclusion and exclusion criteria were enrolled and randomized into two treatment groups using software Rando 1.2 and allocated into either of two treatment groups for 8 weeks. Patients were evaluated at 2,4 , and 8 weeks. One group patients received oral Pregabalin (75 mg BD), while other group patients received oral Nortriptyline $25 \mathrm{mg}$ OD at bed time. Provision of rescue treatment was kept in the form of opioid analgesics in case of inadequate response. 
Dose selection for both the drugs was based on the most commonly used doses [9]. Pain assessment was done by numerical rating scale (NRS) which is indicative of pain intensity on horizontal scale as described by McCaffery and Beebe [10]. NRS consisted of an 11 point in which $0=$ no pain and $10=$ worst possible pain. The patients indicated the numeric value on the segmented scale that best described their pain intensity. Supplemental analysis of the primary efficacy parameter included proportion of responders (patients with $\geq 50 \%$ reduction and patients with $\geq 30 \%$ reduction in mean pain score from baseline) and weekly mean pain scores [11].

The Leeds Assessment of Neuropathic Symptoms and Signs Pain Scale (LANSS) was another efficacy parameter used to assess neuropathic pain. It consists of seven items: Five sensory items and two examination findings (allodynia and pinprick test). More than 12 points out of 24 suggest a neuropathic pain [12].

Safety was assessed by adverse drug reactions (ADRs) recorded on the ADR form provided by Pharmacovigilance Programme of India.

\section{Statistical analysis}

The student t-test (paired) was applied within one treatment group changes from baseline, while student t-test (unpaired) was applied for comparison between two treatments groups. The adverse drug events in the two groups were compared by Fisher's exact test. Chi-square test and student t-test were applied for analyzing the demographic profile. A p-value of $<0.05$ was considered statistically significant.

\section{RESULTS}

A total of 48 patients of PHN participated in the study. The demographic and baseline characteristics of the patients are shown in Table 1.

There was a significant decrease in post drug mean NRS scores in both groups from baseline during entire 8 weeks trial $(\mathrm{p}<0.0001)$. On comparison, there was no difference between two groups except at 8 weeks $(\mathrm{p}=0.0073)$ where pregabalin treatment showed more improvement (Table 2).

Percentage of responders with $\geq 30 \%$ reduction in NRS score was $100 \%$ in both the groups and percentage $\geq 50 \%$ reduction in mean NRS score was $95.83 \%$ and $65 \%$ in pregabalin and nortriptyline group, respectively.

LANSS pain scale showed significant decrease in both treatment arms from baseline score $(\mathrm{p}<0.0001)$. On intergroup comparison, no difference was observed except at 8 weeks $(p=0.0032)$ where pregabalin group showed more improvement (Table 3).

Total six adverse drug events occurred in total of 48 patients $(12.5 \%)$ with two patients in pregabalin group and four in nortriptyline group. The various ADRs reported were nausea, headache, drowsiness, and dry mouth (Table 4), No statistical difference was observed between two groups $(\mathrm{p}=1)$. All the adverse events were mild and did not warrant any cessation/change of therapy.

\section{DISCUSSION}

In the present study, the efficacy and safety of pregabalin and nortriptyline were compared in patients of PHN. All patients were in higher age group with most common involvement of thoracic dermatome (64.58\%), which was similar to earlier reports $[7,13]$. Herpes zoster virus located in the dorsal root ganglion gets reactivated in old age leading to the degeneration of the spinal nerve sensory system and increased neuropathic pain [14].

NRS and LANSS pain scores were significantly reduced by both drugs. Reduction in pain scale scores with pregabalin has been reported by number of studies $[15,16]$. Gabapentinoids counter pain by central analgesic action and also inhibit the ectopic discharge from peripheral
Table 1: Demographic profile of patients in pregabalin and nortriptyline groups

\begin{tabular}{|c|c|c|c|}
\hline Parameter & $\begin{array}{l}\text { Pregabalin } \\
\text { group }(n=24)\end{array}$ & $\begin{array}{l}\text { Nortriptyline } \\
\text { group }(n=24)\end{array}$ & $\begin{array}{l}\text { Statistical } \\
\text { significance }\end{array}$ \\
\hline Age (mean \pm SD) & $58.21 \pm 7.6$ years & $57.29 \pm 13.74$ years & \multirow{3}{*}{$\begin{array}{l}t=0.28 \\
p=0.77 \\
\chi^{2}(1) 0.02 \\
p=0.88\end{array}$} \\
\hline $\begin{array}{l}\text { Number of } \\
\text { Males (\%) }\end{array}$ & $16(66.66)$ & $12(50)$ & \\
\hline $\begin{array}{l}\text { Number of } \\
\text { Females (\%) }\end{array}$ & $8(33.33)$ & $12(50)$ & \\
\hline $\begin{array}{l}\text { Residence } \\
\text { Urban (\%) } \\
\text { Rural (\%) }\end{array}$ & $\begin{array}{l}12(50) \\
12(50)\end{array}$ & $\begin{array}{l}14(58.33) \\
10(41.66)\end{array}$ & $\begin{array}{l}\chi^{2}(1) 0.084 \\
p=0.772\end{array}$ \\
\hline $\begin{array}{l}\text { Socioeconomic } \\
\text { status }\end{array}$ & & & \\
\hline $\begin{array}{l}\text { Middle (\%) } \\
\text { Lower (\%) }\end{array}$ & $\begin{array}{l}14(58.33) \\
10(41.66)\end{array}$ & $\begin{array}{l}10(37.5) \\
14(62.5)\end{array}$ & $\begin{array}{l}\chi^{2}(1) 0.750 \\
p=0.386\end{array}$ \\
\hline Dermatome & & & \\
\hline $\begin{array}{l}\text { Thoracic } \\
\text { Cervical } \\
\text { Trigeminal } \\
\text { Lumbosacral }\end{array}$ & $\begin{array}{l}17(70.83) \\
4(16.66) \\
3(12.5) \\
0\end{array}$ & $\begin{array}{l}14(58.33) \\
6(25) \\
3(12.5) \\
1(4.16)\end{array}$ & $\begin{array}{l}\chi^{2}(1) 0.364 \\
p=0.54\end{array}$ \\
\hline
\end{tabular}

Table 2: Comparative effect of pregabalin and nortriptyline on NRS pain score

\begin{tabular}{|c|c|c|c|c|}
\hline Duration & $\begin{array}{l}\text { Pregabalin } \\
(\text { Mean } \pm \text { SD) } \\
(n=24)\end{array}$ & $\begin{array}{l}\text { Nortriptyline } \\
(\text { Mean } \pm \text { SD) } \\
(n=24)\end{array}$ & p-value & $\begin{array}{l}\text { Statistical } \\
\text { significance }\end{array}$ \\
\hline Baseline & $5.67 \pm 0.87$ & $5.7 \pm 0.73$ & 0.8976 & NS \\
\hline 2 Weeks & $4.33 \pm 0.96 * * * *$ & $4.7 \pm 0.86 * * * *$ & 0.1663 & NS \\
\hline 4 Weeks & $3.17 \pm 0.7 * * * *$ & $3.55 \pm 1.0 * * * *$ & 0.1341 & NS \\
\hline 8 Weeks & $2.04 \pm 0.69 * * *$ & $2.65 \pm 0.81 * * * *$ & $0.0073^{*}$ & $\mathrm{~S}$ \\
\hline
\end{tabular}

NRS: Numerical rating scale, The data are shown as mean SD showing comparison between the two groups at baseline, 2 weeks, 4 weeks, and 8 weeks using student unpaired t-test and paired t-test within group. Column shows comparison within group and row depicts comparison between two groups $*_{\mathrm{p}}<0.05, * *_{\mathrm{p}}<0.01, * * * \mathrm{p}<0.001, * * * * \mathrm{p}<0.0001, \mathrm{NS}$ : Not significant

Table 3: Comparative effect of pregabalin and nortriptyline on LANSS pain score

\begin{tabular}{|c|c|c|c|c|}
\hline Duration & $\begin{array}{l}\text { Pregabalin } \\
\text { (Mean } \pm \text { SD) } \\
n=24\end{array}$ & $\begin{array}{l}\text { Nortriptyline } \\
\text { (Mean } \pm \text { SD) } \\
n=24\end{array}$ & p-value & $\begin{array}{l}\text { Statistical } \\
\text { significance }\end{array}$ \\
\hline Baseline & $16.33 \pm 1.99$ & $16.55 \pm 2.04$ & 0.707 & NS \\
\hline 2 Weeks & $15.45 \pm 2.10 * * * *$ & $15.6 \pm 2.54 * * * *$ & 0.824 & NS \\
\hline 4 Weeks & $10.79 \pm 3.2 * * * *$ & $10.8 \pm 2.78 * * * *$ & 0.99 & NS \\
\hline 8 Weeks & $4.2 \pm 2.36 * * * *$ & $6.25 \pm 2.20 * * * *$ & 0.0032 & $\mathrm{~S}^{* *}$ \\
\hline
\end{tabular}

The data are shown as Mean \pm SD showing comparison between the groups at baseline, 2 weeks, 4 weeks, and 8 weeks using student unpaired t-test and paired t-test within group, column shows comparison within group and row depicts comparison between groups $* \mathrm{p}<0.05, * * \mathrm{p}<0.01, * * * \mathrm{p}<0.001 * * * *$ $\mathrm{p}<0.0001$, NS: Not significant, LANSS: Leeds Assessment of Neuropathic Symptoms and Signs

nerve injury due to herpes zoster virus. They block alpha-2 delta-1 subunit of calcium channels leading to decrease in excitatory amino acids and neurotransmitters release and result in analgesic action [6].

Decline in mean NRS and LANSS pain score observed with nortriptyline in current trial is in agreement with the previous report [17]. Nortriptyline acts on serotonergic $\left(5 \mathrm{HT}_{2}\right)$ receptors, increases norepinephrine availability by blocking neuronal uptake and potentiates the activity of the descending inhibitory pathways extending from the brain stem to the dorsal horn of the spinal cord and thus relieves pain [18]. It also increases dopamine availability by blocking its reuptake and activating 
Table 4: Adverse drug events in pregabalin and nortriptyline groups

\begin{tabular}{llll}
\hline $\begin{array}{l}\text { Adverse } \\
\text { drug event }\end{array}$ & $\begin{array}{l}\text { Pregabalin } \\
(\mathbf{n = 2 4 )}(\mathbf{\%})\end{array}$ & $\begin{array}{l}\text { Nortriptyline } \\
(\mathbf{n = 2 4 )} \mathbf{( \% )}\end{array}$ & $\begin{array}{l}\text { Statistical inference } \\
\text { (Fischer's exact test) }\end{array}$ \\
\hline Headache & $1(4.16)$ & Nil & $\mathrm{p}=1$, NS \\
Dizziness & $1(4.16)$ & $1(4.16)$ & \\
Drowsiness & Nil & $2(8.32)$ & \\
Dry mouth & Nil & $1(4.16)$ & \\
\hline
\end{tabular}

$\mathrm{D}_{2}$ receptors. Nortriptyline acts at spinal and supraspinal levels by activating $\mu$ and $\delta$ receptors. Even analgesic properties of nortriptyline are also contributed by the peripheral noradrenergic system [19]. Antidepressants modulate the immune system, which is also involved in neuropathic pain [20].

In the present trial, there were the higher percentage of responders in pregabalin than nortriptyline group. Sabatowskia et al. [21] have shown reduction in pain and high percentage of responders with pregabalin in their 8 weeks trial in patients of PHN. Efficacy was observed as early as week 1 and was maintained throughout the study.

On comparing, pregabalin was more effective than nortriptyline at 8 weeks on NRS $(p=0.01)$ and LANSS $(p=0.005)$. Although there is a paucity of data in literature regarding their direct comparison between pregabalin and nortriptyline, nortriptyline and gabapentin when compared were found equally efficacious on pain scales VAS and SFMPQ scores. However, gabapentin was better tolerated [22].

Total six mild self-limiting ADRs occurred during trial comprised of two in pregabalin and four in nortriptyline numerically favoring the former. However, the superiority of one over other cannot be emphasized as the sample size was very small. Dizziness, somnolence, and edema are the common side effects reported with pregabalin [7,17,23]. Dizziness and headache were reported in the present study with pregabalin; however, no patient suffered with edema. Drowsiness and dry mouth were also reported in the current study in nortriptyline group. TCA are known to have anticholinergic actions [24,25]. Bansal et al. [26] have demonstrated that pregabalin is a better alternative than amitriptyline in diabetic peripheral neuropathy patients as it is associated with fewer adverse effects.

Current study suffers from few limitations. It was of a shorter duration with less number of patients. Long-term efficacy and safety could not be assessed.

\section{CONCLUSION}

Both pregabalin and nortriptyline were effective in reducing pain in PHN. Pregabalin was found to be better than nortriptyline on pain scales at 8 weeks. Both drugs were well tolerated, though pregabalin had less number of ADRs. Pregabalin could be a promising option, though further trials with longer duration and more number of patients are needed to substantiate these results.

\section{FUNDING}

The authors did not receive any funding in conducting the study.

\section{AUTHORS CONTRIBUTION}

Dr K. Khajuria conducted the study, collected, analyzed the data, and prepared manuscript. Dr S. Gupta designed and overall supervised the trial, while Dr D. Kumar supervised statistical analysis and Dr D.R Dogra supervised work at hospital site and Dr V. Khajuria assisted in final manuscript drafting and acted as corresponding author.

\section{CONFLICT OF INTEREST}

The authors declare no conflict of interest associated with this study.

\section{REFERENCES}

1. Strambi FL. Neuropathic pain and sleep. Pain Ther 2017;6:S19-23.

2. Sampathkumar P, Drage LA, Martin DP. Herpes zoster (shingles) and postherpetic neuralgia. Mayo Clin Prac 2009;84:274-80.

3. Johnson RW, Rice AS. Clinical practice. Postherpetic neuralgia. N Engl J Med 2014;371:1526-33.

4. McElveen WA, Sinclair D. Postherpetic Neuralgia Medication 2018. Available from: https:/www.emedicine.medscape.com/ article/1143066-medication. [Last accessed on 2018 Oct].

5. O'Connor AB, Dworkin RH. Treatment of neuropathic pain. An overview of recent guidelines. Am J Med 2009;122:22-32.

6. Verma V, Singh N, Jaggi AS. Pregabalin in neuropathic pain: Evidences and possible mechanisms. Curr Neuropharmacol 2014;12:44-56.

7. Achar A, Bisai S, Biswas R, Besra M, Guharay T, Ghosh T. Amitriptyline versus pregabalin in post herpetic neuralgia: A randomized clinical trial. Turk J Dermatol 2013;7:145-9.

8. Derry S, Wiffen PJ, Aldington D, Moore RA. Nortriptyline for neuropathic pain in adults. Cochrane Database Syst Rev 2015;1:CD011209.

9. Panickar A, Serpell M. Guidelines for General Practitioners on Treatment of Pain in Post-herpetic Neuralgia. United Kingdom: The Shingles Support Society; 2015. p. 1-4.

10. McCaffery M, Beebe A. Pain: Clinical Manual for Nursing Practice. St. Louis, MO: Mosby; 1989.

11. Parsons B, Pan X, Xie L, Chen Y, Ortiz M, Whalen E. Comparison of the efficacy and safety of pregabalin for postherpetic neuralgia in Chinese and international patients. J Pain Res 2018;11:1699-708.

12. Bennett M. The LANSS pain scale: The Leeds assessment of neuropathic symptoms and sign. Pain 2001;92:147-57.

13. Jha A, Siddalingappa K, Herakal K, Malhotra K. Randomized study to compare the effect of pregabalin with fixed-drug combination of pregabalin and methylcobalamin in the patients of postherpetic neuralgia. Indian J Pain 2018;32:63-7.

14. Zhang M, Gao CX, Ma KT, Li L, Dai Z, Wang S, Si JQ. A meta-analysis of therapeutic efficacy and safety of gabapentin in the treatment of postherpetic neuralgia from randomized controlled trials. Biomed Res Int 2018;2018:7474207.

15. Yin J, Pan Y, Zeng Z, Guo J, Yang J, Feng Z. Efficacy of pregabalin in the treatment of postherpetic neuralgia: A meta-analysis of randomized controlled trials. Int J Clin Exp Med 2016;9:20693-701.

16. Wang SL, Wang H, Nie HY, Bu G, Shen XD, Wang H. The efficacy of pregabalin for acute pain control in herpetic neuralgia patients: A metaanalysis. Medicine 2017;96:e9167.

17. Gilron I, Tu D, Holden RR, Jackson AC, DuMerton-Shore D. Combination of morphine with nortriptyline for neuropathic pain. Pain 2015;156:1440-8.

18. Obata H. Analgesic mechanisms of antidepressants for neuropathic pain. Int J Mol Sci 2017;18:2483

19. Bohren Y, Tessier LH, Megat S, Petitjean H, Hugel S, Daniel D, et al. Antidepressants suppress neuropathic pain by a peripheral beta2adrenoceptor mediated anti-TNFalpha mechanism. Neurobiol Dis 2013;60:39-50.

20. Fornasari D. Pharmacotherapy for neuropathic pain: A review. Pain Ther 2017;6:25-33.

21. Sabatowskia R, Galvezb R, Cherryc DA, Jacquotd F, Vincentd E, Maisonobed $\mathrm{P}$, et al. Pregabalin reduces pain and improves sleep and mood disturbances in patients with post-herpetic neuralgia: Results of a randomized, placebo-controlled clinical trial. Pain 2004;109:26-35.

22. Chandra K, Shafiq N, Pandhi P, Gupta S, Malhotra S. Gabapentin versus nortriptyline in post-herpetic neuralgia patients: A randomized, double-blind clinical trial-the GONIP trial. Int J Clin Pharmacol Ther 2006;44:358-63.

23. Liu Q, Chen H, Xi L, Hong Z, He L, Fu Y, et al. A randomized, doubleblind, placebo-controlled trial to evaluate the efficacy and safety of pregabalin for postherpetic neuralgia in a population of Chinese patients. Pain Pract 2017;17:62-9.

24. Atkinson JH, Slater MA, Williams RA, Zisook S, Patterson TL, Grant I, et al. A placebo-controlled randomized clinical trial of nortriptyline for chronic low back pain. Pain 1998;76:287-96.

25. Watson CP, Vernich L, Chipman M, Reed K. Nortriptyline versus amitriptyline in postherpetic neuralgia: A randomized trial. Neurology 1998;51:1166-71.

26. Bansal D, Bhansali A, Hota D, Chakrabarti A, Dutta P. Amitriptyline vs. Pregabalin in painful diabetic neuropathy: A randomized double blind clinical trial. Diabet Med 2009;26:1019-26. 